\title{
Прием лексической трансплантации из русского языка как характерная черта современного украинского разговорного дискурса*
}

\author{
А. В. САВЧЕНКО, М. С. ХМЕЛЕВСКИЙ \\ A. V. SAvChENKo, Department of Slavic Languages and Literatures, National Chengchi \\ University, No. 64, Sec. 2, 116 Zhinan Road, Wenshan District, TW-11605 Taipei City \\ M. S. KHMELEVSKIJ, Кафедра славянской филологии, Санкт-Петербургский \\ государственный университет, Университетская наб., д. 11, RU-199034 Санкт-Петербург \\ School of Slavic Philology, Faculty of Philology, St. Petersburg State University \\ E-mail: savchenko75@mail.ru, chmelevskij@mail.ru
}

(Received: 31 March 2018; accepted: 19 June 2018)

\begin{abstract}
The use of lexical elements (words, expressions, and idioms) of a foreign language in everyday informal communication is a frequent but still little-studied phenomenon in modern linguistics. The present paper is devoted to the question of "lexical transplantation" of various verbal elements (including those of intertextual character) from Russian to Ukrainian as a typical phenomenon in modern communication of native speakers of the Ukrainian language. On the basis of numerous examples and contexts from colloquial speech, the authors present the linguistic nature of such units, their pragmatic functions in the text (both oral and written) as well as their classification.
\end{abstract}

Keywords: language contact, loanwords, lexical transplantation, Ukrainian colloquial discourse, Russian, intertextual elements

Современная украинская языковая ситуация весьма неоднородна, многообразна и настолько мозаична, что это делает ее уникальной среди других славянских языков. Исторически на территории Украины сосуществуют и оказывают взаимное влияние друг на друга сразу несколько языковых кодов, обслуживающих коммуникативный уровень: украинский литературный язык, русский литературный язык, украинские диалекты и городские койне (например, Одесса, Львов), а также такие формы сплетения обоих близкородственных языков, как украинизированная русская речь и суржик, т. е. смесь украинского и русского языков на всех языковых уровнях (МокиЕнко 2000: 278). Причем, в зависимости от ситуации, среды и социолингвистического контекста украинец зачастую способен переходить с одного языкового кода на

* Работа выполнена при финансовой поддержке Российского фонда фундаментальных исследований. Проект «Проведение комплексного социолингвистического исследования роли и функций русского языка в украинском полиязычном пространстве и описание положения русского языка в современной языковой ситуации на Украине» (№ 18-012-00754; шифр ИАС 31.15.69.2018). 
другой (Нещименко 2003: 15). Отдельно упомянем также и влияние польского языка на украинский разговорный язык в западных регионах Украины (Львов, Тернополь), словацкого и венгерского языков в Закарпатье, украинско-русские и украинско-белорусские переходные говоры в пограничных районах, особый язык украинского еврейства (Одесса, Бердычев, Мариуполь) и прочие формы межъязыковых контактов, встречаемых на территории современной Украины.

В свете вышесказанного данную языковую картину дополним еще одним специфическим явлением, весьма характерным для современного живого украинского языка - «лексические вставки» из русского языка в украинскую разговорную речь.

Подобное включение в текст иноязычных вкраплений в оригинальном или трансформированном виде (фонетическое, морфологическое, лексическое уподобление в принимающем языке) мы называем приемом «лексической трансплантации». Он представляет собой специфическую особенность современного разговорного украинского дискурса, достаточно часто наблюдаемую как в устной речи, так и в письменных текстах (в первую очередь, в литературных произведениях современных украинских писателей, например, Ю. Андруховича, С. Жадана, Ю. Винничука и др.).

Данное явление, однако, не тождественно понятию «заимствования», поскольку в принимающем языке рассматриваемые нами «трансплантанты», как правило, имеют эквиваленты, в то время как заимствования заполняют лакуны «безэквивалентности», входя в лексический состав языка. Заимствования фиксируются словарями и нередко попадают в пласт литературной лексики. В этом и состоит их отличие от трансплантантов, с одной стороны, и варваризмов или экзотизмов - с другой. Явление трансплантирования из других языков, как правило, не фиксируется словарями, и в большинстве случаев такие лексические трансплантанты по своей сути окказиональны.

Таким образом, под термином «трансплантант» понимается перенос лексической единицы или нередко целого выражения из одного языка в другой или в оригинальной форме, или в несколько трансформированной, адаптированной в соответствии с фонетическими правилами принимающего языка.

Длительное многовековое историко-культурное соседство, влияние русской классической литературы, а также массовой культуры (кино, музыка, телевидение - самого широкого диапазона по тематике и уровню качества) способствовали возникновению такого уникального в своем роде феномена, как «трансплантация» в украинскую разговорную речь узнаваемых или знаковых фраз, цитат и образов из прецедентных русских текстов (и шире русской культуры, исторически объединяющей Россию и Украину, своего рода «прецедентные феномены») (МАсЕнко 2004: 106). И хотя в любом языке использование прецедентных текстов в разговорной речи - это довольно распространенное явление, но именно в украинской разговорной речи его можно считать уникальным, поскольку подобные «лексические вкрапления» по своему происхождению - не из родного языка (в отличие от случаев ис- 
пользования приема цитирования прецедентных феноменов в русской разговорной речи на родном, русском, языке) (см. Донгй 2003). Данное явление можно назвать «осознанным» лексическим переносом в родной язык частей текста из другого языка в целях создания более яркого экспрессивного, комического эффекта в речи говорящего, языковой (или точнее - межъязыковой) игры, снижения стиля речи и придания более непринужденного характера общения, подражания речи русскоговорящих, политизации тематики и вследствие других причин, которые будут рассмотрены ниже на конкретных примерах из живой речи украинцев.

Использование трансплантантов в большинстве случаев авторски регламентировано: как правило, они используются с определенной прагматической установкой. Главная их характеристика - узнаваемость участниками коммуникации, за счет чего достигается необходимый эмоционально-стилистический и прагматический эффект.

Так, в украинской речи порождаемый эффектом «языковой трансплантации» контраст оказывается еще более ярким, действующим и экспрессивным по сравнению с подобным приемом цитирования прецедентного текста в русском разговорном дискурсе (где он является аутентичным), поскольку, помимо своей узнаваемости, в украинском он все же является иноязычным (но при этом культурологически не инородным). Отметим также, что для русской разговорной речи характерно именно цитирование (или «клиширование») как основной элемент создания комических и экспрессивных контрастов, тогда как для украинского дискурса характерна спонтанность порождаемых в процессе спонтанной речи образов, иронических сравнений, экспрессивных оборотов, среди которых, в частности, обнаруживается и включение в текст легко узнаваемых прецедентных фраз из русского языка.

Рассматриваемое языковое явление наиболее широко представлено в современной украинской живой речи, в повседневном неформальном общении, причем частотность подобных лексических «вставок», по нашим наблюдениям за языком информантов, увеличивается в момент так называемого экспрессивно-эмоционального скачка в речи говорящего. Это можно объяснить целым рядом причин, в частности, сосуществованием нескольких языковых кодов, исторически сложившейся языковой ситуацией, главной чертой которой является фактическое двуязычие большинства жителей Украины, общностью русскоязычной массовой культуры для обоих народов, а также самой природой украинского юмора, который, как было сказано выше, строится на эффекте спонтанности. Рассматриваемое явление также может быть объяснено и проблемой недостаточной разработанности украинского обиходноразговорного языка, украинского просторечия, «книжностью» литературного языка и как следствие - даже некой «ущербностью» языка в непринужденном повседневном общении (см. МАсЕнко 2004: 108). Именно в этой сфере функционирования языка высока потребность в экспрессивных элементах, интертекстемах, цитации из поп-культуры (ставшей прецедентной в языках народов постсоветского пространства): их источником являются фильмы, 
популярная музыка, классическая и массовая литература, рекламные ролики, языковые штампы, клише и цитаты, нецензурная лексика. Недостаточная развитость данного языкового слоя в сопоставлении с русским препятствует развитию украинского просторечия, обиходно-разговорной подсистемы украинского языка. Так, Л. Т. Масенко отмечает: «Категория просторечия относится с городским нормам функционирования языка, а как раз эти формы в украинском языке функционируют неполноценно. [...] Хотя толковый словарь украинского языка и дает определение категории просторечия, оно осталось за пределами украинской лексикографической практики. Помета просторечное касательно украинской лексики отсутствует и в самом толковом словаре, и в переводных русско-украинских словарях, где часто русской помете просторечное в украинской части соответствуют - разговорное, $\phi a-$ мильярное, вульгарное» и т. П.» (МАСЕнКО 2004: 108).

Роль обиходно-разговорного языка и просторечия в разных регионах Украины выполняют различные языки или, скорее, формы двуязычного смешения, т. е. языковые коды: в восточных и южных областях страны - это русский язык с украинскими элементами, в Одессе - одесское городское просторечие, в центральных регионах, включая Киев, - русский язык с характерной украинской интонацией или суржик, тогда как в западных областях роль просторечия, обиходно-разговорного языка, жаргона выполняет украинская речь, намеренно насыщаемая элементами, лексическими вставками и целыми выражениями из российской массовой культуры (САВчЕНкОХмЕЛЕВСКИй 2016: 420), которые в иноязычной языковой среде, несмотря на свою узнаваемость, все-таки будут звучать иначе и выполнять иную языковую и стилистическую функцию, поскольку по своей природе не являются родными и воспринимаются носителями украинского языка не столько с глубинным семантическим пониманием, сколько - скорее - как клишированные языковые маркированные средства экспрессивизации украинской речи, которая по сути своей является книжной, стилистически маркированной и служащей для официально-делового уровня общения. Показательными в этом смысле являются, например, произведения известного современного украинского писателя Ю. Андруховича, мастера игры с разными формами бытования современного украинского языка и различными языковыми кодами.

Описание данного языкового явления можно дополнить высказыванием современной украинской поэтессы О. Забужко - знатока живого украинского слова: «В начале нашего столетия Владимир Винниченко [украинский политический деятель, писатель, драматург - прим. авт.] полушутя-полусерьезно заметил, что за судьбу украинского языка он будет совершенно спокоен только тогда, когда на нем заговорит криминальный мир - когда где-нибудь в темном закоулке ночью его остановит, блескнув на фоне фонаря ножичком, пьяное мурло и чистісінькою українською гавкне: „Руки вгору! В якій кишені гаманець?“ [Руки вверх! В каком кармане кошелек? - перевод авт.], или приблизится женщина легкого поведения и, заманчиво улыбаясь, скажет что-то типа: „Сумуєш, котику? Може, підемо?““ [Скучаешь, котенок? Может, 
пойдем? - перевод авт.]» (ЗАБужко 1999: 340). Фраза как нельзя точно и красочно отражает современную языковую ситуацию Украины с точки зрения затрагиваемой нами проблематики. Действительно, сложно представить себе подобную «чистісіньку українську» из уст первого либо второго представителя криминального мира из вышеприведенной цитаты даже в западных украиноязычных регионах страны.

Согласно нашим наблюдениям за живой украинской речью, «вкрапления» из русского языка по их природе и функциям можно классифицировать следующим образом:

1) языковые штампы и клише (с целью придания экспрессивности и непринужденности речи говорящего): «Короче, що він тобі сказав? - Короче, дело к ночи, я йому подзвонила...»;, «Мені так здаєтся, що в нього минутная слабость»; «А я йому кажу, будь ласка, какие проблемы ? Заходь!»; «Коли ви собі так вирішили - тогда вперед!»; «А ти що не бачиш, в нього вже белая горячка»; «О, подивіться, вже йдуть: це ж братья наши меньшие!» (в шутку о милиционерах - фраза-клише, укоренившаяся в русском языке в XX веке для метафорического ласкового названия животных); «Будьте ж щасливі в новій жизні!»; «Потрясающе, але ж я так не важаю»; «Ну що я тобі можу сказати - красиво жить не запретишь!»; «коли ти зненацька чуєш сухе, мов постріл „Стой! Руки вверх!““ і зупяняєшся...»; «Тепер усіх задавимо. Повсемесно!; Hem-c, гаспада, ніяких консолідацій!»;

2) штампы из массовой российской культуры (кино, музыка, а также другие прецедентные феномены и штампы из так называемого русскоязычного «масскульта»): «А що кава подорожчала? - Перепрошую, де там подорожчала, вже сто лет (языковой штамп) як 5,50. - Добре, нет, мы не плачем и не рыдаем, дайте, будь ласка, дві розчинні» (искаженная фраза из песни популярного фильма «Двенадцать стульев», 1976 г.); «А то в нас прем’єр тількі подивится і все, кончен бал, погасли свечи» (искаженная фраза из стихотворения А. С. Пушкина)»; «Ой, хто це йде? Зараз вам буде - гуляй губерния!» (искаженная фраза из «Мертвых душ» Н. В. Гоголя); «Зачекай, куди ти пійшов? Мені ще треба гроші поміняти! Постой паровоз! Не стучите колеса!» (фраза из песни популярной советской кинокомедии «Операция Ы», 1965 г.); «Зробіть нам, будь ласка, дві кави. - Зараз Бодя прийде та зробить..., бо я вже - ви ж бачите, Пане - никакая (языковой штамп), як в тумане (штамп), я вже як той ежик в тумане!» (название популярного детского мультфильма «Ежик в тумане», 1975 г.); «Історія - це завжди суб’єктивний погляд, а долі

\footnotetext{
1 Здесь и далее приведены примеры, собранные нами в ходе полевых исследований, проводимых в различных регионах Украины в течение последних 10 лет. Нас интересовала прежде всего неподготовленная, спонтанная речь информантов - представителей различных социальных слоев как наиболее показательная для решения поставленных целей и задач по описанию современной, живой и реальной языковой украинской ситуации. В настоящей статье приводим наиболее иллюстративные примеры из собранного нами обширного материала, что представляется крайне важным для анализа языковой и экстралингвистической палитры современной Украины.
} 
людей - це реальні речі реальних родин: Есть только миг - между прошльым и будущим - именно он называется -жизнь!» (фраза из песни для советского фильма «Земля Санникова», 1973 г.); «коли Україна ще не потрапила в союз нерушимыцй республик свободныхх (фраза из советского гимна); «Дух часу, фантасмагорія та пост-модерна іронія створюють читачеві неповторні переживання того, хто посєтил сєй мір в єво мінути роковиє» (цитата из стихотворения Ф.И. Тютчева «Цицерон»);

3) фразы из агиткультуры (так называемые «советизмы»), включая расхожие высказывания, зачастую утратившие авторство: «Я досить собі усвідомлюю, що під час всіх ціх перетворень ми стикатимемося і з перегибами на местах» (фраза из речи И. Сталина, ставшая прецедентной для всего постсоветского пространства); «я собі відкрив цю гілку и сказал поехали, и взмахнул рукой» (фраза из популярной советской песни о Ю. Гагарине на слова Н. Добронравова);

4) отдельные слова, вставленные в украинскую речь, которые или приобретают новое значение, стилистическое наполнение и «живут» в языке, или употребляются как постоянные эпитеты: «Зараз прийдуть „таварищи“ і вам скажуть, що це все неправда» (с нарочитым подчеркиванием русского аканья) - в украинском языке или его вариантах слово таварищ используется в ироничном или саркастичном значении 'коммунист, русский'; «вона ще у школі була дуже советская» (вм. укр. радянська), а также как спонтанные речевые средства: «Різдво для нас - це велике свято, а у Києві всі тількі й знають, що Новый год та Новый год»; «Зачекай, я в кармані подивлюся. Українською не „карман“, а кишеня! - Та яка це кишеня? На такому драному одягу одні карманыл»;

5) неполнозначные, вводные слова и слова-паразиты, характерные для просторечия, как: тоже, вообще, это самое и т. п.: «ну, конечно, це ж таке життя, я ж брехнею не займаюся, я тількі так... я ж просто, я ж вообще»; а также частотные: хорошо, ладно (вм. добре), да (вм. так) и т. п.: «треба відключати себе... як ти викунуєш свою роботу: точно так же і про полон, точно так же про якісь сітуації; «Да, надо же!? Ти б мене не питав у такому разі?»; «Ти мене даже не слухав!»; «3 таким ставлянням до людей люди также будуть ставлятися до тебе»; «Хорошо, скажи мені, будь ласка»;

6) пародирование русской речи в целях придачи «ассоциативного колорита» или эффекта отнесенности самого контекста к русской или русскоязычной действительности с определенным оттенком ерничества или сарказма: «вони всі були наркомані, вміняемые» (жаргонный штамп), «такі собі донбаські хлопці - naųaнbl»; «Уявляєш, після третьої палки лежу в повному трансі, а вона мені: „Сщцо!“»; включая оттенок политизированности русской вставки в украинском тексте как ответная реакция живого языка на актуальные политические события: «Мова - це полє битви: або переможеш, или проиграешь» (из современного лозунга, призывающего украинцев не пользоваться русским языком в бытовом общении и переходить на родной); или пример в том же ключе: «Якщо „какая разніца““ переходіть на українську»; 
7) нецензурная лексика, экспрессивные обороты: «У мене таке враження склалося, що моя тьоща трошкі х...ей страдает»; «різні люди, були люди говно говном»; «Я важаю законодавців, які пишуть такі закони або сволочами, або падлюками».

Таким образом, можно выявить следующие функции трансплантирования: 1) ирония; 2) передача национального колорита (что чаще встречаем в произведениях классической русской литературы); 3) стеб, ерничество и сарказм; 4) снижение стиля общения и переход на просторечный уровень общения.

Использование элементов чужого языка (в нашем случае - русского) в украинской повседневной неформальной коммуникации - достаточно частое и пока еще остающееся не вполне изученным в славистике явление. Однако, как представляется, «транспланирование» в устную речь элементов близкородственного языка заслуживает более пристального лингвистического внимания в рамках изучения современной языковой ситуации Украины, живого украинского языка, описания его обиходно-разговорного стиля. Отметим также, что данная проблематика представляется актуальной и в свете активного развития социальных сетей, где прием трансплантирования «чужеродных» языковых элементов (как отдельных слов, так и фраз, цитат, идиоматики) выполняет целый ряд тексто- и смыслообразующих функций, что было проиллюстрировано нами на вышеприведенных показательных примерах данного явления.

\section{Литература}

Андрухович 2005 = Андрухович Ю. Рекреациї. Львів, 2005.

БЕЛИКОВ-КРысин 2001 = БЕлиКОВ В. И., КРЫСин Л. П. Социолингвистика. Москва, 2001.

БогдАнОВ 1995 = БогдАнов В. В. Прагматика иноязычных вставок в текст. В кн.: Функиионально-текстовые аспекты языковых единиц. Санкт-Петербург, 1995. $8-12$.

Доний 2003 = Доний О. Хай живе суржик! http://artvertep.com/print?cont=227.

ЗАБУжко 1999 = ЗАБУжко О. Хроніки від Фортінбраса. Київ, 1999.

МАСЕНКО 2004 = МАСенко Л. Мова і суспільство. Постколоніальний вимір. Київ, 2004.

МокиЕнко 2000 = МокІєнко В. М. До проблеми мовної політики в Україні: погляд з лінгвістичної відстані. В кн.: Державність української мови і мовний досвід світу. Матеріали Міжнародної конференції. Київ, 2000. 277-282.

НЕЩИМЕНко 2003 = НЕЩиМЕнко Г. П. Языковая ситуаџия в славянских странах. Москва, 2003.

САВЧЕНКО-ХМЕЛЕВСКИй 2008а = САВченКО А. В., ХМЕЛЕВСКИй М. С. «Здаравеньки булы!», или к вопросу о лексической трансплантации (русско-украинские параллели в национально-культурном дискурсе). В кн.: Материаль международной научно-практической конференџии к юбилею проф. А. М. Мелерович. МоскваКострома, 2008. 177-181. 
САВЧЕНКО-ХМЕЛЕВСКИЙ 2008b = САВЧЕНКО А. В., ХМЕЛЕВСКИЙ М. С. Межславянские лексические трансплантации в современной прессе. В кн.: Wyraz i zdanie w językach słowiańskich 6. Opis, konfrontacja, przekład. Wrocław, 2008. 403-408.

САВЧЕНКО-ХМЕЛЕВСКИЙ 2016 = САВчеНКО А. В., ХМЕЛЕВСКИЙ М. С. РУсский текст в украинском разговорном языке. В кн.: Студї з філології та журналістики. Ужгород, 2016. 420-425.

СТРIXА 1998 = СТРІХА М. Суржик та літературна мова. В кн.: Нариси украӥнської популярної культури. Київ, 1998. 629-637.

ФЛАЙЕР 2010 = ФЛАЙЕР М. С. Суржик или суржики. В кн.: Исследования по лингвистике и семиотике. Сборник статей к юбилею Вяч. Вс. Иванова. Москва, 2010. 281-295.

ХМЕЛЕВСКИЙ 2017 = ХМЕЛЕВСКИй М. С. «Языковой портрет» современной Украины социолингвистический аспект. Komunikacja specjalistyczna 13. Warszawa, 2017. 79-104.

ХМЕЛЕВСКИЙ-УРСУЛЕНко 2009 = ХМЕЛЕВСКИй М. С., УРСУЛЕНКО А. В. Современная украинская языковая ситуация (коммуникативный аспект). In: Heidelberger Publikationen zur Slavistik. (Linguistische Reiche 17.) Frankfurt am Main, 2009. 217-230. 